\title{
RESISTENSI DAN NEGOSIASI PERAN PEREMPUAN \\ DALAM ROMAN MEDEA. STIMMEN KARYA CHRISTA WOLF
}

\author{
Asih Gunawiayu \\ Fakultas Ilmu Budaya, Universitas Padjadjaran \\ asih_gunawiayu@yahoo.com \\ N. Rinaju Purnomowulan \\ Fakultas Ilmu Budaya, Universitas Padjadjaran \\ n.r.purnomowulan@unpad.ac.id \\ Sri Rijati Wardiani \\ Fakultas Ilmu Budaya, Universitas Padjadjaran \\ sri.rijati@unpad.ac.id
}

\begin{abstract}
Abstrak
Penelitian ini bertujuan untuk mengungkap resistensi dan negosiasi peran perempuan dalam Roman Medea. Stimmen karya Christa Wolf. Permasalahan yang dibahas adalah sikap dan tindakan Medea yang ditunjukkan dalam meresistensi dan menegosiasi peran perempuan pada Roman Medea. Stimmen. Dalam penelitian ini digunakan teori naratologi dari Bal (2009), dan konsep peran perempuan dalam masyarakat patriarkal yang dikemukakan oleh Figes (1986) dan Greer (1999). Penelitian ini menggunakan metode deskriptif kualitatif. Hasil penelitian menunjukkan bahwa sikap dan tindakan Medea yang meresistensi dan menegosiasi peran perempuan merupakan mekanisme yang dilakukan agar ia dapat bertahan dalam masyarakat patriarkal, sekaligus tetap memiliki otoritas terhadap dirinya.
\end{abstract}

Kata kunci: peran perempuan; resistensi; negosiasi; Medea

\begin{abstract}
This research aims at conveying the resistance and negotiation of female roles in Roman Medea. Stimmen by Christa Wolf. The issue discussed is how Medea's attitudes and actions in resisting and negotiating the female roles depicted in roman Medea. Stimmen. The theories used in this research are narratology of Bal (2009), and the concept of female roles in the patriarchal society proposed by Figes (1986) and Greer (1999). This research used qualitative descriptive method. The results of this research show that Medea's attitudes and actions in resisting and negotiating the female roles are her mechanism of surviving in the patriarchal society, and defending the authority of her own self.
\end{abstract}

Keywords: female roles; resistance; negotiation; Medea

\section{PENDAHULUAN}

Dalam tiap fase kehidupannya, setiap individu memiliki status tertentu. Lindsey (2016) berargumentasi bahwa status merupakan salah satu struktur sosial terpenting yang mengatur interaksi sosial. Status dipahami sebagai posisi 
yang menjadi faktor penentu seseorang diperlakukan. Terkait dengan status yang dimiliki, seseorang dibebankan peran yang harus dijalani. Peran didefinisikan oleh Lindsey (2016) sebagai tingkah laku yang diharapkan sesuai dengan status seseorang. Peran dijalankan menurut norma-norma sosial, yakni seperangkat peraturan bersama yang menuntun tingkah laku manusia dalam tiap situasi. Namun demikian, peran yang dibebankan kepada perempuan kerap mengopresi. Dijelaskan oleh Figes (1986) bahwa peran yang dijalani oleh perempuan berasal dari perintah dan harapan laki-laki. Seseorang dibebankan peran sesuai dengan status yang dimilikinya. Dalam kesusastraan, kerap diangkat isu mengenai peran perempuan. Salah satu karya sastra yang menampilkan isu tersebut adalah Roman Medea. Stimmen karya Christa Wolf. Karya sastra berbahasa Jerman ini diterbitkan pertama kali oleh penerbit Luchterhand pada tahun 1996. Penelitian yang meneliti roman Medea. Stimmen sudah pernah dilakukan oleh beberapa peneliti lain.

Roman Medea. Stimmen karya Christa Wolf pernah diteliti oleh Alena Janke di tahun 2010 dengan judul disertasi Antiker Mythos und moderne Literatur: Zum Problem von Tradition und Innovation im Werk von Christa Wolf (,Kassandra" und "Medea. Stimmen") (Mitos Kuno dan Sastra Kontemporer: Isu Tradisi dan Inovasi dalam Karya Sastra Christa Wolf) pada Program Studi Bahasa, Sastra, Media \& Bahasa dan Sastra Eropa, Universitas Hamburg, Jerman. Penelitian tersebut menggunakan teori resepsi sastra untuk menganalisis fungsi mitos kuno dalam sastra kontemporer dan bagaimana hal tersebut diresepsi. Hasil penelitian tersebut menunjukkan bahwa sastra kontemporer memungkinkan pengarang untuk menampilkan mitos kuno dengan makna baru sebagai bentuk representasi suatu hal atau peristiwa di suatu zaman.

Penelitian kedua adalah penelitian Jitka Jannesová yang berjudul Antická mytologie $v$ díle Christy Wolf (Mitologi Kuno dalam Karya Sastra Christa Wolf) (2015). Tesis Program Studi Kajian Jermanik, Universitas Karlova, Ceko tersebut menggunakan metode sastra bandingan untuk meneliti perbandingan penggabungan unsur mitos yang sama dalam teks sastra karya Christa Wolf dengan teks sastra karya Aeschylus dan Euripides. Penelitian ini mengungkapkan bahwa bentuk pengangkatan mitos yang dilakukan oleh Wolf dalam karyanya merupakan suatu bentuk perlawanan terhadap cara penyajian mitos dalam karya sastra penyair Yunani kuno.

Penelitian ketiga adalah penelitian yang ditulis oleh Charlotte D'Eer (2014) dengan judul Gendering von Emotionen in Christa Wolfs Kassandra und Medea. (Penggenderan melalui Emosi dalam Erzählung Kassandra dan Roman Medea. Stimmen karya Christa Wolf). Penelitian tersebut merupakan tesis pada Program Studi Bahasa dan Sastra Jerman dan Inggris, Universitas Gent, Belgia. Dalam penelitiannya, D'Eer menggunakan pendekatan struktural dan psikoanalisis untuk menganalisis perbedaan pengungkapan emosi dalam relasi kuasa antargender pada dua sistem, yakni matriarki dan patriarki. Penelitian ini mengungkapkan bahwa dalam kedua objek penelitian, Wolf menolak stereotipisasi emosi berdasarkan gender, dan ia pun tidak mengikuti sistem hirarki patriarki. 
Penelitian keempat adalah penelitian yang dilakukan oleh Gisela Weingartz dengan judul "The Dark Place Where Talent Leads": The Merits and Shortcomings of Feminist Criticism in the Study of Selected Works by Christa Wolf (2001). Penelitian tersebut merupakan tesis Program Studi Bahasa Afrikanas, Belanda, dan Eropa Modern, University of the Free State, Afrika Selatan. Dalam penelitian ini digunakan teori resepsi sastra, dan kritik feminis untuk menganalisis karya-karya sastra Christa Wolf. Hasil penelitian Weingartz menunjukkan bahwa pandangan Wolf terhadap matriarki berbeda dengan filosofi feminis. Dalam Roman Medea. Stimmen, Wolf mendekonstruksi unsurunsur mitos yang asli, sehingga ia dapat mengisahkan ulang mitos tersebut dari sudut pandang perempuan.

Keempat penelitian tersebut memiliki persinggungan dengan penelitian ini berupa penggunaan objek penelitian yang sama. Akan tetapi, dari segi aspek pembahasan, penelitian ini berbeda dengan keempat penelitian terdahulu tersebut. Dalam penelitian pertama, pembahasan difokuskan pada fungsi mitos kuno dalam sastra kontemporer. Penelitian kedua membahas perbandingan penggabungan unsur mitos yang sama antara teks karya Christa Wolf dan karya Aeschylus dan Euripides. Penelitian ketiga membahas perbedaan pengungkapan emosi dalam relasi kuasa antargender pada dua sistem yang berbeda, yakni matriarki dan patriarki. Teks keempat membahas pandangan Wolf terhadap matriarki dalam karya sastranya. Berbeda dengan keempat penelitian tersebut, penelitian ini berfokus membahas resistensi dan negosiasi terhadap peran perempuan yang dilakukan oleh tokoh Medea. Oleh karena itu, posisi penelitian ini menjadi penting bagi penelitian lanjutan yang menganalisis roman Medea. Stimmen.

Permasalahan yang dibahas dalam penelitian ini adalah bagaimana sikap dan tindakan Medea ditunjukkan dalam meresistensi dan menegosiasi peran perempuan pada roman Medea. Stimmen. Berangkat dari permasalahan tersebut, penelitian ini bertujuan untuk mengungkapkan sikap dan tindakan Medea yang ditunjukkan dalam meresistensi dan menegosiasi peran perempuan.

\section{METODE PENELITIAN}

Metode yang digunakan dalam artikel ini adalah deskriptif kualitatif. Pengunaan metode tersebut bertujuan untuk memecahkan masalah yang sedang dianalisis dengan memaparkan objek penelitian berdasarkan data yang ditemukan. Objek penelitian ini merupakan karya sastra berbahasa Jerman berjudul Medea. Stimmen karya Christa Wolf. Data yang ditemukan dalam objek penelitian akan dianalisis melalui kata, kalimat, maupun paragraf yang mengandung informasi terkait resistensi dan negosiasi peran perempuan yang dilakukan oleh tokoh Medea. Narasi mengenai Medea dalam objek penelitian dituturkan melalui teks polifonik yang mencakup enam perspektif tokoh. Terminologi polifonik dijelaskan Behzadi (2015) sebagai teks yang terdiri atas dua atau lebih suara-suara yang bersifat independen. Suara-suara tersebut saling terkait, dan tiap suara dipersepsi sebagai suara yang setara kedudukannya.

Dari objek penelitian, data dikumpulkan melalui metode pustaka, kemudian data yang terkumpul akan dianalisis dan diinterpretasi dengan 
menggunakan teori naratologi dari Mieke Bal (2009), dan didasarkan pada konsep peran perempuan dalam masyarakat patriarkal menurut Eva Figes (1986) dan Germaine Greer (1999). Analisis naratologi bertujuan untuk menelaah aspek-aspek yang dianggap penting dalam teks, maupun aspek yang relevan dengan rumusan masalah (Nünning \& Nünning, 2010). Oleh karena itu, dengan menggunakan teori naratologi, penelitian ini akan menganalisis tokoh, narator, dan fokalisasi dalam objek penelitian. Bal (2009) mendefinisikan tokoh sebagai tokoh antropomorfik dengan ciri-ciri tertentu yang diketahui pembaca melalui narator. Informasi mengenai tokoh dalam teks didapatkan pembaca dari narator. Bal (2009) menyatakan bahwa narator merupakan konsep paling pokok dalam analisis teks naratif. Lebih lanjut, Bal mendefinisikan narator sebagai "agent which utters the (linguistic or other) signs which constitute the text" (2009:18). Narator dalam teks dapat menarasikan suatu tokoh, atau dapat pula menjadi tokoh tersebut.

Dijelaskan oleh Bal (2009) bahwa terdapat dua jenis narator, yakni external narrator dan character-bound narrator. Perbedaan kedua jenis narator tersebut terletak pada objek yang dinarasikan. Pada external narrator, narator dalam teks tidak pernah secara eksplisit mengacu kepada dirinya sendiri sebagai tokoh, melainkan menarasikan tokoh lain. Sedangkan pada character-bound narrator, narasi yang dilakukan oleh narator mengacu kepada dirinya sendiri sebagai tokoh.

Narator bersama fokalisasi menentukan situasi naratif. Fokalisasi menurut Bal (2009) adalah aspek teknis berupa penempatan sudut pandang pada agen tertentu. Bal (2009) menambahkan bahwa fokalisasi merupakan hubungan antara penglihatan, agen yang melihat, dan apa yang terlihat. Berdasarkan definisi fokalisasi yang mengacu pada suatu hubungan, maka dalam fokalisasi terdapat hubungan antara subjek dan objek. Dalam melakukan analisis, keduanya harus ditelaah secara terpisah.

Subjek fokalisasi, yakni fokalisator, adalah subjek yang memandang elemen-elemen dalam teks (Bal, 2009). Fokalisator dapat menjadi satu maupun terpisah dengan suatu tokoh. Mengenai hal tersebut, Bal (2009) memaparkan dua jenis fokalisator, yaitu character-bound focalizer, dan non-character-bound focalizer. Character-bound focalizer adalah fokalisator yang tergabung dengan suatu tokoh. Penempatan fokalisator yang demikian disebut sebagai internal focalization. Dibandingkan tokoh lainnya, tokoh yang terikat dengan fokalisator akan mendapat keuntungan karena pembaca melihat menggunakan "mata" tokoh tersebut, sehingga akan cenderung menyetujui pandangannya. Fokalisator jenis ini dapat beralih dari satu tokoh ke tokoh lain, meskipun narator dalam teks tidak berubah. Meskipun demikian, fokalisator jenis ini memiliki kelemahan, yakni dapat menimbulkan bias dan pembatasan. Jenis selanjutnya, yakni noncharacter-bound focalizer adalah fokalisator yang merupakan agen anonim yang berada di luar cerita. Penempatan fokalisator jenis ini disebut sebagai external focalization.

Melalui fokalisator pembaca mengetahui objek fokalisasi. Bal (2009) menguraikan bahwa fokalisator membentuk gambaran mengenai objek. 
Gambaran yang ditampilkan tersebut juga menunjukkan sesuatu tentang fokalisator itu sendiri. Bal (2009) lebih lanjut memaparkan beberapa pertanyaan yang relevan dalam analisis fokalisasi. Pertama, apa yang difokalisasi oleh tokoh, dan apa yang dituju? Kedua, bagaimana tokoh melakukan fokalisasi, dan dengan sikap apa fokalisator memandang sesuatu? Ketiga, siapa yang memfokalisasi, dan objek mana yang difokalisasi? Yang dapat difokalisasi tidak harus berupa tokoh, tetapi dapat pula berupa objek, pemandangan, peristiwa, dan lain-lain.

Karena fokalisasi merupakan penempatan sudut pandang pada agen tertentu, maka interpretasi yang dihasilkan tidak dapat bersifat netral. Bal (2009) menyatakan bahwa fokalisasi juga memiliki efek manipulatif, sehingga pembaca dimanipulasi untuk berpihak pada fokalisator. Dalam proses analisis, pembaca harus tetap memerhatikan perbedaan antara kata yang diutarakan dan kata hati tokoh. Kata yang diutarakan dapat "didengar" oleh tokoh lain, sedangkan kata hati yang berupa pemikiran, atau monolog dalam diri, tidak dapat diketahui oleh tokoh lain. Bal (2009) menyatakan suatu bentuk khusus dari fokalisasi, yakni kenangan. Kenangan merupakan suatu tindakan melihat masa lalu. Sebagai suatu tindakan, kenangan terletak di masa kini dari ingatan tokoh. Kenangan juga merupakan sambungan antara waktu dan ruang. Waktu yang telah berlalu, dan ruang yang pernah disinggahi oleh tokoh dalam objek penelitian.

Untuk mengungkapkan lebih dalam mengenai resistensi dan negosiasi peran perempuan yang dilakukan tokoh Medea, artikel ini mengacu pada konsep peran perempuan dalam masyarakat patriarkal dari Figes (1986) dan Greer (1999) yang menjelaskan peran perempuan sebagai anak, istri, dan rekan kerja yang dikonstruksi oleh masyarakat patriarkal. Dalam masyarakat patriarkal, perempuan dituntut untuk menjalankan tiap peran sesuati dengan statusnya dalam masyarakat. Pada awal kehidupannya, perempuan memiliki status sebagai anak. Figes (1986) berargumentasi bahwa anak perempuan secara alamiah bergantung pada keputusan laki-laki dalam keluarganya. Pendidikan anak perempuan sejak awal harus direncanakan sedemikian rupa dengan pertimbangan kepentingan laki-laki. Anak perempuan harus dididik agar dapat mendapatkan rasa hormat dan cinta dari laki-laki. Sikap dan tindakan anak perempuan harus membuat hati laki-laki senang dan berbahagia. Oleh karena itu, dapat disimpulkan bahwa peran perempuan sejak kecil dikonstruksi sedemikian rupa demi kepentingan laki-laki.

Setelah menikah, perempuan mendapatkan status sebagai istri. Diuraikan oleh Greer (1999) bahwa tugas pertama seorang istri adalah selalu bersiap sedia untuk kepentingan suaminya. Seorang istri harus dapat membangun rasa percaya diri suaminya, memberikan ketenteraman, dan melayani segala kebutuhan jasmaniah suaminya. Dalam masyarakat patriarkal, istri yang menunaikan tugas-tugas tersebut barulah dapat disebut sebagai aset bagi suaminya (Greer, 1999). Jika perempuan tidak sepenuhnya tunduk pada keinginan suaminya, maka ia akan dianggap sebagai perempuan yang melawan hukum alam (Figes, 1986). Padahal dalam kenyataannya yang disebut sebagai "hukum alam" tersebut adalah konstruksi yang dibangun oleh masyarakat patriarkal demi melanggengkan kuasa patriarki. Oleh karena hal tersebut, perempuan yang menolak untuk patuh akan dijatuhi hukuman. Hukuman 
tersebut berlaku sebagai alat pelanggengan kuasa patriarki. Hukuman tersebut berupa kecaman dari suami, dan perempuan yang tidak tunduk tersebut dianggap pantas untuk tidak lagi dicintai (Figes, 1986). Ditambahkan oleh Greer (1999), jika istri tidak menjalankan peran dengan baik, maka suami dapat bersikap dingin dan membuat jarak dalam kehidupan berumah tangga.

Selain dalam lingkup kehidupan pribadi, dalam dunia kerja pun perempuan dituntut untuk menjalankan peran tertentu. Sebagai rekan kerja, perempuan dikondisikan untuk meyakini bahwa pekerjaan laki-laki lebih berat dan menekan, meskipun dalam kenyataannya tidak demikian (Greer, 1999). Diargumentasikan oleh Greer (1999) bahwa dalam kenyataannya, laki-laki sebenarnya tidak suka bekerja, dan berambisi untuk tidak melakukan apapun. Hal tersebut berbanding terbalik dengan perempuan. dalam kesehariannya, perempuan selalu menyibukkan diri, sehingga menyebabkan munculnya rasa jengkel laki-laki kepada perempuan yang memasuki "wilayahnya" (Greer, 1999). Perempuan yang bekerja dianggap mengambil sesuatu yang harusnya hanya dikuasai oleh laki-laki.

\section{HASIL DAN PEMBAHASAN}

Analisis dalam penelitian ini dibagi menjadi tiga bagian pembahasan. Pertama, pembahasan Medea dalam perannya sebagai anak perempuan. Kedua, pembahasan Medea dalam perannya sebagai istri. Terakhir, pembahasan Medea dalam perannya sebagai rekan kerja perempuan di antara rekan-rekan kerja lakilaki.

Peran dipahami sebagai seperangkat tingkah laku yang diharapkan terkait dengan status seseorang. Peran yang dibebankan kepada seseorang tergantung status yang dimilikinya. Dalam pelaksanaannya, peran dijalankan dalam batas norma-norma sosial masyarakat. Dalam masyarakat patriarkal, perempuan harus memenuhi standar keperempuanan agar dipandang sebagai perempuan yang utuh. Standar keperempuanan, termasuk di dalamnya terdapat peran yang harus dijalani perempuan, bukan ditentukan oleh perempuan, melainkan oleh laki-laki demi kepentingan laki-laki (Figes, 1986). Tidak ada tawar menawar dalam pemenuhan standar tersebut, sebab sebagaimana yang dinyatakan oleh Figes (1986), jika seorang perempuan tidak dapat memenuhi standar tersebut, maka ia sama sekali bukan perempuan.

Dalam roman Medea. Stimmen, tokoh Medea dihadirkan sebagai perempuan yang menyadari otoritas terhadap diri dan pikirannya sendiri, meskipun ia tinggal di lingkungan masyarakat patriarkal. Berikut kutipan data yang menunjukkan hal tersebut.

Ich bin keine junge Frau mehr, aber wild noch immer, das sagen die Korinther, für die ist eine Frau wild, wenn sie auf ihrem Kopf besteht. Die Frauen der Korinther kommen mir vor wie sorgfältig gezähmte Haustiere, sie starren mich an wie eine fremde Erscheinung, [....] (Wolf, 2010:4) 
Aku bukan lagi perempuan muda. Tetapi menurut penduduk Korinth, aku masih liar, karena bagi mereka perempuan yang memiliki pemikiran sendiri adalah perempuan liar. Bagiku, perempuan Korinth terlihat persis seperti hewan peliharaan, tetapi mereka melihatku seolaholah aku adalah suatu momok.

Situasi dalam kutipan di atas merupakan fokalisasi yang hadir dari pertentangan pandangan pribadi tokoh Medea dengan pandangan penduduk Korinth yang menjunjung ideologi patriarki. Karena pemikirannya yang aktif mengancam status quo patriarki, maka ia mendapat sangsi sosial berupa penolakan. Lebih lanjut, dengan pemikiran aktif yang melanggar normativitas, maka penduduk Korinth sebagai agen patriarki menyematkan label penyihir sebagai sesuatu yang menakutkan. "Ich sagte mir, ich bin Medea, die Zauberin, wenn ihr es denn so wollt. Die Wilde, die Fremde. Ihr werdet mich nicht klein sehen." [Aku berkata pada diriku sendiri, aku adalah Medea, sang penyihir, jika kalian menginginkan aku demikian. Aku si perempuan barbar, perempuan asing. Kalian tidak bisa meremehkan aku] (Wolf, 2010:89). Pelabelan tersebut juga mengindikasikan adanya penolakan masyarakat Korinth terhadap Medea.

\section{Tokoh Medea sebagai Anak Perempuan}

Pada bagian ini dianalisis sikap dan tindakan Medea dalam menjalankan perannya sebagai anak perempuan. Medea ditampilkan sebagai anak perempuan Raja Aietes dari Kolchis. Kedatangan Jason dan pasukan Argonaut ke Korinth bertujuan untuk meminta bulu domba emas milik Raja Aietes. Hal tersebut ditampilkan dalam kutipan berikut.

Sie führte uns zu ihrem Vater, dem König Aietes, der empfing uns, überrumpelt, Medea stellte uns ihm förmlich vor und ging, obwohl er sie bat, in befehlendem Ton, sie solle bleiben. Sie ging. (Wolf, 2010:21)

Ia (Medea) membawa kami menuju ayahnya, Raja Aietes, yang terkejut menerima kedatangan kami. Medea memperkenalkan kami padanya secara formal, kemudian ia pergi. Meskipun ia (Raja Aietes) dengan nada memerintah menyuruhnya untuk tidak pergi, akan tetapi Medea tetap berlalu.

Penuturan narator Jason dalam kutipan tersebut menunjukkan penolakan Medea untuk mematuhi keinginan ayahnya, meskipun tetap ada komunikasi dalam hubungan antara ayah dan anak tersebut. Medea tetap menghormati Raja Aietes sebagai ayahnya, tetapi dengan tidak mematuhi perintah ayahnya yang tidak sejalan dengan keinginannya sendiri menunjukkan otoritas Medea terhadap dirinya sendiri.

Bulu domba emas milik Raja Aietes merupakan barang yang harus didapatkan agar Jason bisa mendapatkan kembali takhtanya sebagai raja di Iolkos. Untuk mencapai tujuan tersebut, Jason meminta bantuan kepada Medea. 
[...], Du verrätst mich nicht, meine Tochter. Ich wußte, Jason wollte das Vließ. Ich wußte, der König wollte es ihm nicht geben. Warum nicht, das fragte ich nicht. Ich müsse ihm helfen, diesen Mann unschädlich zu machen, um jeden Preis. Ich sah, wie hoch er den Preis ansetzte, zu hoch für uns alle. Mir blieb nichts übrig als Verrat. (Wolf, 2010:12)

Jangan kau khianati aku, putriku. Aku tahu bahwa Jason menginginkan bulu domba itu. Aku tahu bahwa raja (Aietes) tidak ingin memberikannya pada Jason. Tetapi aku tidak bertanya mengapa. Aku harus menolongnya (Jason) agar selamat, apapun bayarannya. Aku melihat betapa tingginya ia (Raja Aietes) menetapkan "harga" yang harus dibayar, terlalu tinggi untuk kita semua (sebagai manusia). Tidak ada pilihan lainnya bagiku, selain mengkhianatinya (Raja Aietes).

Narator di dalam narasi adalah Medea, sedangkan fokalisasi yang hadir berasal dari Raja Aietes dan Medea. Dalam kutipan tersebut terlihat perintah yang diberikan Raja Aietes menekankan otoritasnya atas diri anak perempuannya. Perintah tersebut dapat dimaknai sebagai mekanisme patriarki untuk mendomestifikasi Medea agar tetap "berada" dalam lingkup keluarganya, dalam hal ini berupa keberpihakan pada ayahnya sendiri. Figes (1986) menyatakan bahwa salah satu tugas anak perempuan adalah membuat hati lakilaki dalam keluarganya senang dan hidup mereka berbahagia. Jika Medea berpihak pada ayahnya, maka ia bisa menunaikan tugasnya dalam peran sebagai anak perempuan dengan baik. Namun demikian, batin Medea menolak untuk berpihak pada ayahnya. Ia pun memiliki gagasan untuk melakukan tindakan yang berlawanan dengan keingian ayahnya tersebut. Sikap dan tindakan Medea tersebut merepresentasikan resistensi Medea terhadap konstruksi peran anak perempuan.

\section{Tokoh Medea sebagai Istri}

Setelah membantu Jason mendapatkan bulu domba emas, Medea kemudian menikah dengan Jason. Dari pernikahan tersebut, Medea mendapatkan status baru sebagai istri. Dengan status istri, ada peran baru yang harus diemban olehnya..

Sebelum menikah dengan Jason, Medea merupakan seorang pendeta. Agar ia dapat menjalankan perannya dengan baik sebagai istri, Medea memutuskan untuk melepas statusnya sebagai pendeta kultus. "Ich legte meinen Rang ab. Ich war eine gewöhnliche Frau, in ihrer Hand. So gab ich mich Jason hin, [...] und band ihn dadurch an mich." [Aku melepas posisiku. Aku menjadi seorang perempuan biasa di tangannya (dewi). Dalam keadaan demikian, aku menyerahkan diriku pada Jason, dan mengikat dirinya padaku] (Wolf, 2010:48). Diargumentasikan oleh Greer (1999), salah satu tugas pertama seorang istri adalah selalu bersiap sedia untuk kepentingan suaminya. Kutipan tersebut menunjukkan untuk menjalankan peran dalam status sebagai istri, Medea melepaskan posisinya dalam kultus. Dengan dilepaskannya posisi tersebut, 
maka gugur pula tanggung jawab yang diembannya dalam kultus, sehingga ia dapat memfokuskan diri menjalankan peran di status baru. Setelah dan selama terikat dalam pernikahan, Medea menyerahkan diri kepada suaminya. "[...], noch einmal überließ ich ihm nicht nur meinen Fuß, jeden Flecken meines Körpers, [....]" [Sekali lagi aku menyerahkan diriku padanya, bukan hanya kakiku, tetapi setiap bagian tubuhku] (Wolf, 2010:9). Dari kutipan tersebut terlihat bahwa penyerahan diri secara utuh yang dilakukan Medea terbatas hanya pada raganya saja. Ia sebagai perempuan tetap memiliki otoritas terhadap pikiran dan tindakannya sendiri.

Dalam menjalankan perannya sebagai istri, Medea tidak kehilangan otoritas terhadap pemikirannya. Pemikirannya tersebut yang membuatnya dapat menjalankan perannya dengan baik.

Aber wenn Jason, außer sich vor Angst und Sorge, mich das gleiche fragt und wenn auch er versucht, mich zum Verstummen zu bringen, dann läßt mich das nicht kalt. Dann sage ich ihm, was ich weiß, [....] (Wolf, 2010:48)

Akan tetapi, saat Jason merasa takut dan khawatir, atau saat ia menanyakanku pertanyaan yang sama, dan ketika ia mencoba untuk membungkamku, aku tidak akan merasa gentar. Aku akan mengatakan padanya apa yang aku tahu.

Narasi yang disampaikan Medea menunjukkan bahwa sebagai istri ia memberikan ketenteraman dan menenangkan hati Jason, sebagaimana yang diargumentasikan oleh Greer (1999) bahwa tugas istri dalam masyarakat patriarkal adalah memberikan ketenteraman dan membangun rasa percaya diri suami. Meskipun ia menjalankan perannya sebagai istri, tetapi secara bersamaan ia menolak untuk tunduk kepada ideologi patriarki Jason sebagai agen patriarki menunjukkan ambivalensi. Ia mencoba membungkam Medea karena pemikirannya yang aktif, tetapi ia juga menemukan perlindungan darinya. "Früher hast du mir Kraft gegeben, alle Kräfte, die ich brauchte." [Dulu kau memberikan aku kekuatan, semua kekuatan yang aku butuhkan] (Wolf, 2010:9). Tidak hanya memelihara kondisi mental Jason, tubuh Medea pun diakomodasikan demi kepentingan fisik suaminya. Hal tersebut terlihat dalam kutipan berikut.

Erschöpft, schmutzig schleppte ich mich nach Hause, [...] Hände und Gesicht konnte ich mir rasch noch abspülen, ein sauberes Hemd statt des verdreckten zerrissenen Kleides überwerfen, ehe Jason nach mir rief. (Wolf, 2010:7)

Lelah dan kotor, aku pulang ke rumah. Aku dapat dengan segera membersihkan tangan dan wajahku, serta menanggalkan gaun yang kotor dan sobek serta berganti baju yang bersih, sebelum Jason memanggilku.

Dari narasi yang disampaikan Medea tersebut ditunjukkan bahwa tubuh Medea sebagai istri harus selalu siap kapanpun dan dalam kondisi apapun demi 
kepentingan suaminya. Mengacu kepada argumentasi Greer (1999), salah satu tugas istri adalah melayani segala kebutuhan jasmaniah suaminya. Dengan pelayanan secara fisik dan psikis tersebut, perempuan terus menerus terikat dan mengikatkan diri pada suaminya.

Keterikatan istri secara fisik dan mental dengan suaminya juga secara tidak langsung mengikat perempuan pada ranah domestik..

[...], habe sie auf Wunden gelegt, habe sie zu der Göttin aufgehoben, habe das Wasser vom Brunnen getragen, das Leinen mit unseren Mustern gewebt, habe sie in den warmen Haaren der Kinder vergraben. (Wolf, 2010:2)

Meletakkannya di atas luka, menengadahkannya kepada sang Dewi, menggunakannya untuk mengangkut air dari sumur dan menenun kain dengan pola kita, serta membenamkannya dalam kehangatan rambut anak-anak.

Merujuk pada kutipan, Medea berkutat pada kegiatan domestik. Ia ditampilkan memiliki nilai-nilai femininitas yang normatif. Mengacu kepada argumentasi Greer (1999), istri yang menunaikan semua tugas-tugasnya, termasuk tugas domestik, adalah aset bagi suaminya. Aset dimaknai sebagai sesuatu yang berharga, sehingga istilah "istri sebagai aset" dapat diasumsikan sebagai hak milik suami atas istrinya, suami memiliki kewenangan atas diri istrinya. Dengan demikian, ada pelanggengan kuasa patriarki dalam konstruksi peran perempuan sebagai istri.

Peran istri yang dikonstruksi untuk melanggengkan ideologi patriarki tersebut tidak hanya bermula setelah pernikahan, tetapi anak perempuan sedari kecil secara tidak sadar dipersiapkan untuk menjalankan peran tersebut.

[...] ich ziehe das weiße Kleid an, das ich selbst gewebt und genäht habe, wie du es mir beigebracht hast, dann gehen wir wieder gemeinsam durch die Gänge unseres Palastes, und ich werde froh sein, wie ich es als Kind gewesen bin [....] (Wolf, 2010:3)

Aku memakai gaun putih yang ku tenun dan jahit sendiri, seperti yang kau ajarkan padaku. Kemudian, kita berjalan bersama lagi melalui koridor-koridor dalam istana kita, dan aku akan merasa bahagia sebagaimana yang aku rasakan semasa kecil dulu.

Kata bercetak tebal dalam kutipan mengindikasikan peristiwa yang terjadi di masa lalu. Medea dalam kutipan tersebut sedang menuturkan kenangan bersama ibunya. Kenangan dijelaskan oleh Bal (2009) sebagai suatu tindakan melihat masa lalu. Kenangan merupakan sambungan antara waktu yang telah berlalu dan ruang yang pernah disinggahi. Dari kenangan Medea akan waktu yang dilewati bersama ibunya, diketahui bahwa nilai femininitas normatif dalam masyarakat patriarkal dikenal pertama kali oleh anak perempuan dari 
keluarganya, dalam hal ini ibunya. Hal ini sejalan dengan argumentasi Lindsey (2016), bahwa anak-anak mengenal nilai dan perangkat tingkah laku, termasuk yang berkaitan dengan gender, melalui keluarga.

Tugas yang harus dilakukan dalam perannya sebagai istri, dan kesadarannya akan otoritas tubuh dan pikirannya membuahkan konflik internal dalam diri Medea.

Ist das Fest vorüber, oder muß ich noch hingehen, wie ich es Jason schließlich zugesagt habe. Du kannst mich jetzt nicht im Stich lassen, Medea, von diesem Fest hängt viel ab. Nicht für mich, habe ich ihm gesagt, und das weißt du auch, aber meinetwegen, ich komme, habe ich zu ihm gesagt, [....] (Wolf, 2010:2)

Apakah perjamuannya telah selesai, atau aku harus pergi, seperti yang telah aku janjikan pada Jason. Kau tidak boleh mengecewakan aku sekarang, Medea, banyak hal yang bergantung pada perjamuan ini. Tidak untukku, kataku padanya, dan kau (Jason) pun mengetahuinya, tetapi demi dirimu, aku datang, itulah yang aku katakan padanya.

Narator Medea dalam kutipan tersebut memfokalisasi konflik dalam hatinya. Di satu sisi ia tidak ingin berada di tempat tersebut, tetapi di sisi lain ia merasa harus tetap tinggal demi suaminya. Sebagaimana yang diargumentasikan oleh Greer (1999) bahwa salah satu tugas seorang istri adalah bersiap sedia untuk kepentingan suaminya, maka meskipun tidak menginginkan untuk hadir, Medea menekan perasaannya demi kepentingan suaminya. Hal ini menunjukkan bahwa tokoh Medea menunjukkan adanya negosiasi yang harus dilakukan dalam menjalani peran sebagai istri.

Negosiasi yang dilakukan Medea dalam menjalankan peran sebagai istri tidak dapat begitu saja diterima oleh agen patriarkal, dalam hal ini suaminya.

Wenn sie nicht so hochmütig wäre. Schließlich war sie die Flüchtige, angewiesen auf mich. [...] Das habe ich ihr immer wieder sagen müssen. Und sie? Ich bin nicht von Kolchis weg, um mich hier zu ducken, solche Reden führt sie und bindet ihren wilden Haarbusch nicht ein, wie die Frauen von Korinth es nach der Hochzeit tun, und sagt noch: Na und? findest du mich nicht schöner so? Die Unverschämte. Weiß ganz genau, was ich schön, wen ich am schönsten finde. Und läuft durch die Straßen wie ein Ungewitter und schreit, wenn sie zornig ist, und lacht laut, wenn sie froh ist. (Wolf, 2010:27)

Jika ia tidak begitu angkuh. Bagaimana pun, ia adalah orang yang melarikan diri, ia bergantung padaku. Hal itu berulang-ulang kukatakan padanya. Dan bagaimana tanggapannya? Aku tidak pergi dari Kolchis untuk menjadi pengecut disini, itulah yang dikatakannya, dan ia menolak untuk mengikat rambut tebalnya yang tidak teratur sebagaimana yang dilakukan oleh perempuan Korinth yang sudah menikah. Ia berkata lagi: terus kenapa? Bukannya aku lebih cantik seperti ini? Dasar tidak tahu malu. Aku tahu benar seperti apa yang menurutku cantik. (Medea) berlari-lari di jalanan seperti badai, dan berteriak saat ia marah, dan tertawa keras saat ia bahagia. 
Jason merasa ketidakpatuhan Medea sebagai istri mengancam status quo budaya patriarki. Dengan mengungkapkan emosinya secara terbuka, Medea dianggap keluar dari norma femininitas yaitu perempuan sepatutnya bersikap pasif dan dependen. Meskipun Medea menjalankan semua tugas domestik dalam perannya sebagai istri dengan baik, akan tetapi hal tersebut belum cukup selama ia tidak menempatkan diri sebagai yang subordinat di hadapan suaminya. Dengan menolak subordinasi, Medea dianggap telah melakukan pelanggaran. Melalui kalimat "dasar tidak tahu malu" Jason mengecam Medea yang menolak untuk patuh. Hal ini sejalan dengan argumentasi Figes (1986) bahwa perempuan yang tidak sepenuhnya tunduk pantas untuk mendapat kecaman dari suaminya. Dengan demikian dapat diargumentasikan bahwa Jason sebagai agen patriarkal tidak dapat menerima negosiasi peran yang dilakukan istrinya.

Saat kedua pihak bersalah, maka suami akan cenderung mencari pembenaran dan menyalahkan istri yang berada di posisi subordinat. "Vor allen Leuten war jetzt ich der betrogene Mann und nicht sie die verlassene Frau, [...]. Recht geschah ihr, der Hure." [Di depan semua orang, sekarang akulah suami yang ditipu. Bukan dia yang dipandang sebagai istri yang diabaikan. Itulah dia, si sundal] (Wolf, 2010:100). Dari kutipan tersebut, terlihat Jason merasa kecewa. Kekecewaan tersebut ditransformasi menjadi kecaman. Sundal dalam kutipan tersebut mengacu kepada Medea. Dengan menggunakan kata tersebut, Jason merendahkan diri Medea, dan mengacu kepada makna dari kata sundal, Medea diposisikan setara dengan perempuan jalang.

Konflik dalam hubungan Medea dan Jason tersebut mengakibatkan hubungan yang semakin renggang antara keduanya. Renggangnya hubungan mereka terlihat dalam komunikasi dalam kutipan berikut.

Sie fragte: Was willst du noch. Ihr Ton brachte mich auf. [...] Sie sagte: Schade um dich, Jason. Das war zuviel. Das mußte ich mir nicht bieten lassen. Ich konnte auch anders. Meiner Wut ihren Lauf lassen. Mich an sie heranmachen und sie gegen die Wand drängen. (Wolf, 2010:101)

Dia bertanya, apa yang kau inginkan sekarang? Nada bicaranya membuatku marah. Dia berkata, harusnya kau malu akan apa yang telah kau lakukan, Jason. Keterlaluan. Tidak pantas ia berkata seperti itu padaku. Aku dapat bersikap berbeda. Aku dapat meluapkan amarahku. Menyerangnya dan menghantamkannya ke dinding.

Narator Jason memfokalisasi situasi komunikasi antara dirinya dan Medea pasca konflik. Keengganan Medea untuk bersikap sebagai yang subordinat menjadi justifikasi kemarahan dan tindak kekerasan yang akan dilakukan Jason. Tindak kekerasan secara verbal dan fisikal tersebut merupakan mekanisme patriarki untuk membuat Medea kembali kepada nilai femininitas normatif.

Dari analisis yang dilakukan, ditemukan bahwa Medea melakukan negosiasi terhadap konstruksi peran yang harus dijalankan istri. Ia menjalankan 
tugas-tugas dalam peran istri yang dikonstruksi oleh budaya patriarki. Akan tetapi, Medea juga menunjukkan otoritas terhadap diri dan pemikirannya sendiri. Melalui sikap dan tindakan yang dilakukannya, ia memosisikan diri setara dengan suaminya.

\section{Tokoh Medea sebagai Rekan Kerja Perempuan}

Dengan kemampuan dan pengetahuan yang dimiliki Medea, ia bekerja pada kerajaan Korinth sebagai tabib dan ahli nujum. Di samping mengabdi sebagai tabib kepada keluarga kerajaan, Medea pun menyembuhkan penduduk Korinth yang sakit. Sebelum kedatangan Medea, di negeri yang baru tersebut telah ada tabib dan ahli nujum yang semuanya berjenis kelamin laki-laki. Sehingga, Medea yang turut bekerja dalam kedua bidang tersebut kemudian mendapat status baru sebagai rekan kerja perempuan.

[...], mit ihrem Holzkästchen und der weißen Binde um die Stirn durch die Stadt zu laufen, zum Zeichen, daß sie als Heilerin unterwegs war [...], und jedermann hat sie respektiert, und die Familien, in denen sie einem Kranken geholfen hat, verbreiteten ihr Lob. Es wurde Mode in Korinth, sich an sie zu wenden und nicht an die Astrologen oder an die Ärzte aus der Schule des Akamas. (Wolf, 2010:27)

Medea bepergian di dalam kota dengan membawa peti kayu kecil, serta memakai balutan kain putih di dahinya, tanda bahwa ia sedang dalam perjalanan untuk mengobati. Setiap orang menghormatinya, dan keluarga dari orang-orang yang telah ia sembuhkan menyebarkan tentang kebaikannya. Kemudian, menjadi kebiasaan di Korinth untuk berkonsultasi dengannya daripada dengan para ahli nujum atau tabib dari sekolah milik Akamas.

Jason sebagai narator memfokalisasi Medea dalam pekerjaannya. Dari narasi tersebut diketahui bahwa Medea dalam pekerjaannya secara tidak langsung "mengambil alih" wilayah kekuasaan laki-laki. Di lingkungan masyarakat Korinth yang menjunjung ideologi patriarki, Medea sebagai perempuan melanggar batasan nilai femininitas perempuas dengan bekerja di luar ranah domestik. Sebagaimana yang diargumentasikan oleh Greer (1999) bahwa perempuan yang bekerja dianggap mengambil sesuatu yang harusnya hanya dikuasai oleh laki-laki. Pekerjaan Medea di luar ranah domestik tersebut mengancam langgengnya ideologi patriarki. Dengan bekerja, perempuan tidak lagi pasif dan dependen. Perempuan yang bekerja berarti perempuan yang memiliki keahlian, pemikiran, dan kemampuan untuk mendapatkan uang. Hal tersebut menjadikan perempuan mandiri, sehingga tidak lagi bergantung kepada laki-laki.

Meskipun Medea hanya menjalani pekerjaannya, tetapi kehadirannya tetap mengintimidasi rekan-rekan kerjanya. Bidang yang sebelumnya hanya dikuasai oleh laki-laki, kini didominasi oleh Medea. Hal tersebut terepresentasikan dalam kutipan berikut. 
Ich wollte es kaum glauben, daß dies sein Ernst war, [...], begriffich, daß es ihm zupaß kommen mußte, wenn er Beweise gegen Medea in die Hand bekam. [...] Daß er es satt hatte, aufihre Unfehlbarkeit mit gleicher Unfehlbarkeit antworten $z u$ müssen, um sich in ihrer Gegenwart nicht unterlegen zu fühlen. (Wolf, 2010:35)

Aku sulit memercayai bahwa ia serius. Aku mengerti bahwa ia akan merasa senang saat mendapatkan bukti untuk melawan Medea. Ia merasa lelah harus terus menghadapi kepandaian Medea dengan kepandaian yang seimbang, agar ia tidak merasa inferior di hadapan Medea.

Narator dalam kutipan tersebut adalah Agameda, tetapi fokalisasi terdapat pada tokoh Akamas, rekan kerja Medea. Kutipan tersebut mengindikasikan adanya hubungan yang tidak harmonis antara Medea dan rekan kerja laki-lakinya. Hal ini sejalan dengan argumentasi Greer (1999) bahwa laki-laki akan merasa jengkel pada perempuan yang memasuki "wilayahnya", dalam hal ini bidang pekerjaan. Kecerdasan yang dimiliki Medea membuat rekan-rekan kerjanya merasa terintimidasi. Dengan kecerdasan tersebut, Medea menunjukkan bahwa ia setara dengan laki-laki. Hal tersebut merupakan ancaman bagi kelanggengan budaya patriarki. Untuk menjaga status quo, maka Medea yang dianggap sebagai ancaman berusaha untuk disingkirkan.

\section{PENUTUP}

Sikap dan tindakan yang meresistensi dan menegosiasi peran perempuan yang dilakukan oleh Medea dalam roman Medea. Stimmen merupakan mekanisme yang dilakukan agar ia dapat tinggal dalam masyarakat patriarkal sekaligus memiliki otoritas terhadap dirinya sendiri sebagai perempuan. Sistem patriarki mengonstruksi tingkah laku perempuan sesuai dengan statusnya dalam masyarakat (Lindsey, 2016). Peran perempuan yang dikonstruksi tersebut ditujukan demi kepentingan laki-laki. Sebagai anak perempuan, Medea meresistensi konstruksi peran yang dibebankan kepadanya. Kepada ayahnya, ia bersikap formal dan menjaga jarak. Ia pun menolak patuh pada perintah dan permintaan ayahnya. Kemudian, setelah berstatus sebagai istri, Medea melakukan negosiasi terhadap perannya. Terhadap suaminya, ia bersikap peduli. Dalam rumah tangganya, ia melakukan semua tugas dalam perannya sebagai istri, tetapi ia juga mempertahankan otoritas akan diri dan pikirannya sendiri. Akan tetapi, suaminya tidak dapat menerima negosiasi peran yang dilakukan Medea, sehingga ia menghukum Medea dengan kecaman sebagai mekanisme patriarki untuk mengembalikan Medea kepada nilai femininitas normatif. Terakhir, sebagai rekan kerja perempuan, Medea bersikap profesional dalam pekerjaannya. Akan tetapi, oleh karena keahlian yang dimilikinya "mengintimidasi" rekan kerja laki-laki, dan pilihannya untuk bekerja di luar ranah domestik melawan ideologi patriarki, maka ia disingkirkan. 
Penyingkiran tersebut merupakan mekanisme patriarki untuk menjaga status quo budaya patriarki.

\section{DAFTAR PUSTAKA}

Bal, M. (2009). Narratology: Introduction to the Theory of Narrative. Toronto: University of Toronto Press.

Behzadi, L. (2015). Introduction: The Concept of Polyphony and the Author's Voice. In L. Behzadi, \& J. Hämeen-Anttila, Concepts of Authorship in PreModern Arabic Texts (pp. 9-22). Bamberg: University of Bamberg Press.

D'Eer, C. (2014). Tesis. Gendering von Emotionen in Christa Wolfs Kassandra und Medea . Ghent, Belgium: Universiteit Gent.

Figes, E. (1986). Patriarchal Attitudes. London: Macmillan.

Greer, G. (1999). The Whole Woman. New York: Anchor Books.

Janke, A. (2010). Disertasi. Antiker Mythos und moderne Literatur: Zum Problem von Tradition und Innovation im Werk von Christa Wolf (,Kassandra" und „Medea. Stimmen") . Hamburg, Germany: Universität Hamburg.

Jannesová, J. (2015). Tesis. Antike Mythologie im Werk Christa Wolfs . Prague, Czech Republic: Univerzita Karlova.

Lindsey, L. L. (2016). Gender Roles. New York: Routledge.

Nünning, V., \& Nünning, A. (2010). Methoden der literatur- und kulturwissenschaftlichen Textanalyse. Stuttgart: Verlag J. B. Metzler.

Weingartz, G. (2001). Tesis. "The Dark Place Where Talent Leads": The Merits and Shortcomings of Feminist Criticism in the Study of Selected Works by Christa Wolf. Bloemfontein, South Africa: University of the Free State.

Wolf, C. (2010). Medea. Stimmen. Berlin: Suhrkamp Verlag. 